\title{
Retraining Due to Illness ant its Implications in Nursing Management
}

\author{
Joseli Maria Batista ${ }^{1}$ \\ Carmen Maria Casquel Monti Juliani² \\ Jairo Aparecido Ayres ${ }^{3}$
}

\begin{abstract}
There is currently an increased interest in workers' health. Retraining due to illness is the topic of this study. The objective of this qualitative study was to understand how individuals cope with job retraining in a public hospital, utilizing interviews to understand how nursing professionals coped with the retraining process, which were then analyzed using Content Analysis as proposed by Bardin. The responses revealed problems in several areas of nursing work: "Work Organization", "Teamwork", "Sick leave and retraining", and "Team Management", altogether generating suggestions for improving the work experience in retraining. The retraining process generated individual, professional and social feelings of incompetence and guilt for workers. Important reflection and attitude changes are urgently needed, supporting team management, which will consequently improve care provided to the public.
\end{abstract}

Descriptors: Nursing; Occupational Health; Health Manpower; Management.

\footnotetext{
${ }^{1}$ RN, M.Sc. in Nursing, Hospital Regional de Assis, Brazil, e-mail: joslibat@hra.famema.br.

2 Ph.D. in Nursing, Faculty, Faculdade de Medicina de Botucatu, Universidade Estadual "Julio de Mesquita Filho", Brazil, e-mail: cjuliani@fmb.unesp.br.

${ }^{3}$ Ph.D. in Tropical Biology, Faculty, Faculdade de Medicina de Botucatu, Universidade Estadual "Julio de Mesquita Filho", Brazil, e-mail: ayres@fmb.unesp.br.
}

Corresponding Author:

Carmen Maria Casquel Monti Julian

Departamento de Enfermagem. Faculdade de Medicina de Botucatu. Univeri-

sidade Estadual "Julio de Mesquita Filho"

Campus Universitário da Medicina. Bairro Rubião Junior

CEP: 18603-970 Botucatu, SP, Brasil

E-mail: cjuliani@fmb.unesp.br 


\section{O processo de readaptação funcional e suas implicações no gerenciamento em enfermagem}

Hoje há maior interesse pelo trabalhador da saúde. A preocupação com o processo de readaptação funcional foi a proposta desta investigação. O objetivo foi compreender a vivência dos sujeitos nos processos de readaptação funcional, em uma instituição hospitalar pública. No estudo, qualitativo, foram realizadas entrevistas para apreensão da vivência do profissional de enfermagem quanto ao processo de readaptação funcional, analisadas utilizando a Análise de Conteúdo, proposta por Bardin. Os resultados evidenciam a problemática do processo de trabalho em enfermagem nas categorias "organização do trabalho", "trabalho em equipe", "afastamento e readaptação funcional" e "gerenciamento da equipe", gerando sugestões para a melhoria dos processos de trabalho. O processo de readaptação funcional gera individual, profissional e socialmente sentimento de incompetência e culpa no trabalhador. Importantes reflexões e mudanças de atitude são urgentes e necessárias, subsidiando o gerenciamento da equipe que implicará em melhoria na assistência prestada à população.

Descritores: Enfermagem; Saúde do Trabalhador; Recursos Humanos em Saúde; Gerência.

\section{El proceso de readaptación funcional y sus implicaciones em la administración de enfermería}

Actualmente existe mayor preocupación con el trabajador de la salud. La preocupación con el proceso de readaptación funcional fue la propuesta de esta investigación. El objetivo fue comprender la vivencia de los sujetos en la readaptación funcional en una institución hospitalaria pública. En el estudio, cualitativo, fueron realizadas entrevistas para captar la vivencia del profesional de enfermería en lo que se refiere al proceso de readaptación funcional, con Análisis de Contenido propuesto por Bardin. Los resultados colocan en evidencia la problemática del proceso de trabajo en enfermería, en las categorías "Organización del trabajo", "Trabajo en equipo", "Licencia de trabajo y readaptación funcional" y "Gerencia del equipo", lo que generó sugestiones para la mejoría de los procesos de trabajo. El proceso de readaptación funcional genera individualmente, profesionalmente y socialmente sentimiento de incompetencia y culpa en el trabajador. Importantes reflexiones y cambios de actitud son necesarios para subsidiar la administración del equipo que, por consecuencia, implicará mejoría en la asistencia prestada a la población.

Descriptores: Enfermeria; Salud Laboral; Recursos Humanos en Salud; Gerencia.

\section{Introduction}

Workers' health is one of the priorities currently established in health services because it reflects on sick leave and on situations that require functional readaptation.

Systems are supported in the logic of productivity and rationalization of resources in a capitalist society, hence, the discourse about concern with workers' health does not always result in effective actions. Work overload, connivance of managers with poor working conditions might consequently have a negative effect on the quality of care delivered.

This study was carried out in a public hospital and originated from the concern that arose from this context and the desire to better understand it. The perception that workers suffer in the face of the re-adaptation process coupled with the scarcity of publications about the theme triggered the interest in the study, which was guided by the following question: how do workers experience the 
process of illness and functional retraining?

Understanding and reflection about the way readaptation processes develop and also their implications for management in nursing justify the development of this study, since implications for personal, social and managerial spheres can all be identified in these processes. Many of these implications are inherent to nursing teamwork itself, which reflects on the care delivered to patients. Care quality is only achieved when the institution becomes involved and values workers and their respective work conditions.

Thus, we aimed to understand the experience of the process "from disease to functional retraining" based on the reports of formally re-adapted members of the nursing team.

\section{The retraining process and the nursing context}

Nursing workers whose historical archetypes are focused on intense dedication to work, submission to other professionals in the health fields and who are exposed to environmental and psychosocial risks leave their occupational activities only when harm to their health becomes unbearable.

Functional re-adaptation is defined as "locating employees in functions or activities and responsibilities compatible to their limitation imposed by their physical or mental capacity, verified by medical examination"(1).

The Quality of working life (QoWL) of nursing professionals is undermined due to aspects related to inadequate remuneration, imbalance between work processes and extra-organizational life, to the lack of prospects for career ascension, to the bureaucratic organizational culture and lack of human resources ${ }^{(2)}$.

Nursing management requires the leadership to be able to observe her/his team in an integral and integrating way. Nurses can identify the emergence of occupational diseases and interfere in work organization through their educational and leader's role.

\section{Methodological Path}

This qualitative study is analyzed through thematic content analysis(3). This technique objectively and systematically describes communication-laden content, involving pre-analysis, exploration, categorization, treatment and interpretation of results.

The study was carried out in a general hospital in the interior of São Paulo, Brazil with semi-structured interviews, applied after the Ethics Research Committee at the studied institution (n.47/2007 March $8^{\text {th }}$ 2007) approved the research project and free and informed consent forms were signed by the participants.

The inclusion criterion was being a formally readapted member of the nursing team. All the nursing workers meeting this condition were invited to participate, totaling 10 individuals fitting the study's timeframe. Nine people, one nurse and eight nursing auxiliaries participated in the study. The nurse and one of the nursing auxiliaries were on sick leave even after formal re-adaptation. The remainder were performing clerical activities, four in hospitalization units and two in outpatient units.

Interviews about their experience with the process "from disease to functional re-adaptation" were carried out by the researcher herself, recorded and transcribed between September 2007 and February 2008. The following questions guided the interviews: "what do you think contributed to your health problem and sick leave? Do you have any suggestions to prevent or diminish this kind of problem? What did functional re-adaptation mean and how do you feel in your current activity? Do you want to add any observation or comment? The participants worked in hospitalization or outpatient units, which are not identified in order to preserve the participants' anonymity.

Letters were used in the participants' narratives in order to ensure their anonymity, i.e. A means the unit three of the subject's report called A.

\section{Results and Discussion}

On average, interviewees were 47.9 years, had graduated 21.6 years ago and worked in the institution for 14.1 years. The pathologies that led to the readaptation process were diseases of the musculoskeletal system and connective tissue in seven individuals, mental and behavioral disorders, especially depression in one individual, and injuries, poisoning and some other consequences of external causes in one individual. Three were kept in nursing activities with some limitations after re-adaptation, four were kept in clerical functions and two were still on sick leave.

The individuals' reports led to units of meanings that were grouped into 11 themes, which in turn composed four categories.

From category A, work organization, emerged the themes work overload, disease denial, diagnosis and care, night shift and shift rotation, and workers' health as reports indicate.

[...] and you can't do anything by yourself, and repetitive 
movements, take the blood pressure of 32 patients by yourself, temperature by yourself $[\ldots]$ (A3)

[...] what really contributed to it was having pain but keeping working, not looking for [...] the right, adequate treatment [...] insisting on keeping working, not telling that I wasn't well (B3).

[...] my husband [...] paid for the surgery because I couldn't take it anymore [...] I was emotionally bad off! The psychologist took care of me, helped me a lot [...] (C5).

$[\ldots]$ they arrived in the middle of the night from an accident [...] the patient had blood all over him. It was me and the driver [...] we got the gurney and I pulled it to my side and [...] I didn't realize and then I started to feel pain (D2).

$[\ldots]$ the legal department [...] advised me to retire [...] I was on leave for 2 and a half, three years. Then, it was denied (the retirement) and right after that my re-adaptation was announced, I didn't even know it. It was an action from the medical experts; nobody called me from the hospital [...] (E5).

[...] I went to a physician, applied ointment, physiotherapy, did this and that and nothing, then I went to an occupational physician [...] she studied it [...] she even got a CAT (occupational accident report) but she never reported it! With a witness and [...] (C3).

Nursing work overload and shift schedule were perceived as aggravating factors in a work that generates occupational diseases. The evaluation of consequences of diseases on workers and the level of incapacity at the time of diagnosis influence their capacity to resume their $\operatorname{activity}^{(4)}$.

One has to establish a method of organizing work that allows a rotation of activities according to the competence of each category without harming care delivery, patients, or the institution itself(5).

Nursing workers are exposed to several burdens such as biological, chemical, and psychological and we also observed mechanical and physiological loads such as the manipulation of excessive weight, standing, inappropriate positions and night shifts and shift rotation in the analyzed category ${ }^{(6)}$.

These conditions contribute to the development of muscoskeletal disorders. The type of activities and the intense work rhythm in addition to the work organization itself are possibly causal factors related to the occurrence of these injuries ${ }^{(7)}$.

Nursing workers "put aside" their own health, which evidences the influence of the historical archetype, in which self care is subservient to patient care. Professionals resist acknowledging the disease or incorporating preventive actions.

Health workers show a strong concern for client care and little concern for the risks they are exposed to when delivering care(8)

Being constantly exposed to concrete risks, workers tend to naturalize them as a mechanism of defense to preserve psychological survival. Risks are unconsciously accepted as part of the job ${ }^{(9)}$.

The delay in diagnosing diseases and lack of health care available to health workers contribute to increasing concern over the Single Health System and its representatives in providing health to its health workers. Therefore, resolutions, regulating standards and occupational health committees (COMSAT) in hospital facilities are established ${ }^{(10)}$.

This scenario is already changing the studied institution with the implementation of a committee called COMSAT, which is constituted by one coordinating nurse, two generalist physicians and two nursing auxiliaries. Although the team does not meet all the current needs, it attends workers, follows-up on occupational accidents, promotes educational activities and promotes supervisorial activities in the facility supervises.

Difficulties are experienced, especially due to a lack of workers' knowledge regarding their role as agents responsible to prevent the injuries to which they are exposed to and also as participants in the process of recovering their own health.

There is clear lack of training both of health professionals and human resources professionals in terms of care, follow-up and guidance on clinical and social aspects and also on the worker rights of readapted workers. These factors reveal a poor view of a human being's integrality, which is the basic proposal of the Single Health System in Brazil.

A behavioral change is needed in professional education, which needs to focus on workers' health and on the process of work organization so workers are valued and respected in terms of both their potentialities and their limitations.

In category $\mathrm{B}$, teamwork, the themes team pressure and team support emerged, revealing the interface of difficult relationships within the group and the effect of lack of information and communication of conflicts.

[...] the leadership did not see it [...]didn't believe I was sick [...]I had no support, they would laugh in my face and at the end they said I was hindering the sector's work [...] (A4).

The team accepted me well, at least it seems they are happy $[\ldots]$ (F11).

My colleague called me and asked me to help her, to answer a phone call and I stayed, but the boss never said: "Stay, help, do it!" (D28). 
The team's relationship issues evidence the resistance of health professionals in accepting the disease process. They do not acknowledge or question the severity of the disease. This situation reproduces occupational violence, in which the nursing team is the victim, which seeks to defend itself through verbal aggressions within the group itself and shows indifference to the suffering of any of its members ${ }^{(11)}$.

Difficulties are manifested during teamwork, which incite feelings of exclusion in nursing workers on sick leave because they lose the ties with the group, aggravating their already fragile state caused by the disease. There are also other related factors such as resentment generated by the frequent need to attend medical expertise visits, long lines during such visits, and comments of neighbors and acquaintances ${ }^{(12)}$.

Conflicting relationships and inappropriate communication lead to false judgments, insecurity, and disbelief, negative and pejorative feelings directed at the worker who needs to be relieved from work. The health professionals themselves need to recover the integral health concept as set out by the World Health Organization (WHO).

Poor work conditions coupled with difficulties in relationships harm the daily and private lives of workers(13). Suffering increases as efforts exerted to satisfy needs in the affective, political, social and material spheres are not fully effective ${ }^{(14)}$. The quality of working relations along with group conflicts lead to psychological imbalance(15-16).

Category $\mathrm{C}$ includes the sick leave burden and functional re-adaptation. Relevant facts are expressed in reports through the themes the sick leave burden, negative feelings and benefits of re-adaptation. Given the scarcity of research on this subject, we focused on the discussion that we believe contributes to management in nursing.

[...] I suffered a lot, got depressed. I don't even like to recall it, swear to God! I suffered a lot. I was relieved from my functions for one year and ten months [...] (G1).

[...] The re-adaptation was even worse. I didn't know it caused so many nuisances to my colleagues, my work and even in the family (E1).

At the beginning of the re-adaptation, it's kind of weird because you feel a little devalued. It's like you were demoted from your function, you know? (F6).

This re-adaptation was a blessing for me! [...] I'm still useful, productive, and that is important to me [...] (B7).

[...] It was good for me! I was relieved [...] I lived in the expectation I'd go back to work [...] I called and asked [..] I know I'm limited in my function, but I want to work! (C13).

[...] I was and still am a very happy person because I do something for others, even in re-adaptation. I'm happy even with my problem, in the unit ( $\mathrm{H} 4)$.

[...] I say on my last workday in the month: "Thank my Lord for another month I was able to work!" (seems touched) (D47).

Working is a source of satisfaction for human beings because it provides for material, emotional, social and power needs.

Some have the impression that some symptoms and pain are only in the mind of patients/workers or that they are pretending. Some believe they want to have some secondary gain when they complain of pain(12). If this is the case, this behavior should be investigated to find out what are its determinants.

Impeded in exercising their professional role, the feeling of insecurity and loss of identity in addition to the feeling of uselessness lead workers to have negative feelings about their value in their family and society, which generates self-expectations and a denial of the disease's development.

Even while being part of the nursing team, the re-adapting worker feels isolated. Workers are not always qualified to perform a new function when they are relocated into another sector and oftentimes are considered to be an additional problem for the people in the new sector. Their activities are frequently considered to be less complex, hence, they are devalued.

The study reveals that the experience of readaptation is negative when it is imposed on the workers unilaterally. A possible solution to these limitations should be constructed along with the team responsible for the worker's health problem(s) or in public health services, such as COMSAT, the management to which workers are subject to and the nursing professional her/ himself.

However, the feeling is positive when the readaptation process means changes with the permission and participation of workers, when they expect new experiences and to recover a relationship with peers and management characterized by mutual respect. The work/ disease continuum is no longer a source of suffering for nursing workers and becomes a source of satisfaction by feeling useful and productive again.

Working plays a more important role in the struggle against illness than has been supposed in scientific conceptions. The notion of work should figure in the definition of health itself as a fundamental right that contributes to health and social work [...] Talking about 
"social well being" without giving these conceptions a precise content seems to be a mistake ${ }^{(13)}$.

Category D, team management, reflected the leadership nurses assume in the organization over teamwork processes. Two themes emerged: organization and management and education and training.

[...] my boss told me that whatever I did when came back I'd be collaborating! [...] Only that saying is one thing [...] and doing is another [...] (D29).

[...] my sick leave expired and I went back to work but they hadn't allocated me anywhere. I was like a "cheap dizzy", didn't know what to do! (I43).

I wish they'd (leadership) notice us more, not just me, but my colleagues as well. I wish they'd send us to places we could work with less pain... (D40).

[...] make workers to see a physician [...] regularly have to medical check-ups[...] anything can be solved if you take care of it in time $[\ldots]$ (B8).

[...] I guess that more has to be explained about readaptation [...] $(\mathrm{H} 6)$.

Through communication management can enable the exchange of ideas and measure workers' needs and also validate their knowledge and experiences, considering the potential of each and the team's catalyzing effect.

When work is organized in a humanized way, considering the participation of workers and taking into account group decisions, it promotes change and valorization ${ }^{(5,17)}$. Hence, a participative administration does not mean the leadership's responsibilities are reduced $^{(12)}$.

A previous study ${ }^{(18)}$ on nursing team sick leave indicates the need for leadership to better analyze the occupational situation in their purview, since improved working conditions positively affects economic and social costs.

More than improving access through quality of facilities and equipment, one needs to rethink humanization at work, participation of professionals in management, working conditions and support to professionals, valuing and motivating them. The delivery of humanized care to patients should be coupled with humanized care to health professionals.

Re-adaptation of nursing workers leads to managerial problems including the development of working shift scales. Considering institutional standards and the complexity of care and work processes, nurses should seek solutions in partnership with the team, the institution and the worker her/himself to avoid the lack of perspective at work, dissatisfaction and illness.

\section{Considerations}

This study focused on the category Functional Re-adaptation, which was not well represented in the literature. Thus, the importance of this study is to complement knowledge in the field, since it might promote reflection on and changes in this process.

The contradictory feelings that emanate from agents who experience this process, from negative, painful and suffering moments to feeling reborn afterwards, from these who oftentimes are devoid of emotional support, technical guidance and support for work problems, led to the desire to seek for potential solutions.

The recovery of nursing workers' health promotion is essential, stressing that many of these injuries are predictable, hence preventable.

Nursing management can, through its team's knowledge and in an integral way, promote organizational and educational actions to improve the workers' quality of life. These actions should not be restricted to the leadership's sphere of competence but they also should be linked at institutional levels that are related to the problem such as the Human Resources Department, COMSAT and the hospital's command.

Denying or omitting the problem should be avoided so that the way workers' health is addressed is transformed in this historical moment and the concept of integrality in health is effectively considered.

\section{References}

1. Governo do Estado de São Paulo. Procuradoria Geral do Estado. Estatuto dos Funcionários Públicos Civis do Estado. Lei n. 10.261 , de 28 de outubro de 1968. São Paulo: Centro de Estudos; 2004.

2. Menzies IEP. A Case-Study in the Functioning of Social Systems as a Defence against Anxiety: A Report on a Study of the Nursing Service of a General Hospital. Human Relations 1960 may; 13:95-121.

3. Bardin L. Análise de conteúdo. Lisboa: Persona edições; 2008.
4. Barbosa RMC. O processo de readaptação profissional em um hospital público: percepção dos trabalhadores de enfermagem portadores de doenças osteomusculares. [Dissertação] Belo Horizonte (BH): Universidade Federal de Minas Gerais; 2004.

5. Martins JT, Robazzi MLCC, Plath GA. Satisfação e insatisfação entre auxiliares e técnicos de enfermagem de uma unidade de internação feminina de um hospital-escola. Cienc enferm 2007 junho; 13(1):25-33.

6. Zapparoli AS, Marziale MHP. Risco ocupacional em unidades de suporte básico e avançado de vida em emergências. Rev Bras 
Enferm 2006 janeiro/fevereiro; 59(1):41-6.

7. Leite $\mathrm{PC}$, Silva A, Merighi MAB. A mulher trabalhadora de enfermagem e os distúrbios osteomusculares relacionados ao trabalho. Rev Esc Enferm USP 2007; 41(2):287-91.

8. Oliveira BRG, Murofuse NT. Acidentes de trabalho e doença ocupacional: estudo sobre o conhecimento do trabalhador hospitalar dos riscos à saúde de seu trabalho. Rev Latino-am Enfermagem 2001 janeiro/fevereiro; 9(1):109-15.

9. Elias MA, Navarro VL. A relação entre o trabalho, a saúde e as condições de vida: negatividade e positividade no trabalho das profissionais de enfermagem de um hospital escola. Rev Latinoam Enfermagem 2006 julho/agosto; 14(4):517-25.

10. Resolução SS-5, de 16/01/2006. Institui nas unidades da Secretaria de Estado de Saúde, a Comissão de Saúde do Trabalhador, COMSAT. DOE 18/02/2006. São Paulo: Secretaria de Estado da Saúde de São Paulo; 2006.

11. Mishima SM, Villa TCS, Silva EM, Gomes ELR, Anselmi ML, Pinto IC, et.al. Organização do processo gerencial no trabalho em saúde pública. In: Almeida MCP, Rocha SMM, organizadoras. O trabalho de Enfermagem. São Paulo (SP): Cortez; 1997. p. 251-96.
12. Ministério da Saúde (BR). Doenças relacionadas ao trabalho: manual de procedimentos para serviços de saúde. In: Dias EC, organizador. Representação OPAS/OMS. 2001. Brasília: MS; 2001.

13. Dejours C. A loucura do trabalho: estudo da psicopatologia do trabalho. São Paulo: Cortez-Oboré; 2003.

14. Mendes AMB. Os novos paradigmas de organização do trabalho: implicações na saúde mental dos trabalhadores. Rev Bras Saúde Ocup. 1995 setembro; 85/86(23):55-60.

15. Morillejo EA, Muñoz CP. Fatores de risco em trabalhadores da saúde. Rev Tec Cient Enferm 2004 maio/junho; 2(9):138-45 16. Backes DS, Lunardi Filho WD, LunardiVL. Humanização no ambiente hospitalar a luz da política de humanização da assistência à saúde. Enferm Bras 2005 julho/agosto; 4(4):227-31.

17. Rocha AM, Felli VEA. A saúde do trabalhador de enfermagem sob a ótica da gerência. Rev Bras Enferm 2004 julho/agosto; 57(4):453-8.

18. Barboza DB, Soler ZASG. Afastamentos do trabalho na enfermagem: ocorrências com trabalhadores de um hospital de ensino. Rev Latino-am Enfermagem 2003 março; 11(2):177-83. 